UDK 339.138:994.738.5

\author{
Bilovodska Olena, \\ D. Sc. (Economics), Professor, \\ Taras Shevchenko National University of Kyiv, \\ Department of International Economics and Marketing, \\ Kyiv; ORCID ID 0000-0003-3707-0734 \\ e-mail: alenabel79@gmail.com \\ Holovachov Ivan, \\ PhD Student 075 Marketing, \\ Kyiv National University of Technologies and Design, \\ Kyiv; e-mail: ivan.holovachov@gmail.com
}

https://doi.org/10.29038/2786-4618-2021-03-90-95

\title{
SYSTEMATIC RESEARCH OF DIGITAL MARKETING STRATEGY TOOLS
}

In the 21 st century, when technology is evolving rapidly and there is unlimited access to information, there is no denying that the world we live in is changing rapidly. The rapid development of science, globalization, the transition to the information society and the digital economy have contributed to a significant transformation of society. Currently, the world is creating a global digital space, so globalization and digitalization - the main trends of today, which to a greater or lesser extent cover all countries. Digitalization is a general term for the digital transformation of society and the economy. It describes the transition from the industrial age and analog technologies to the age of knowledge and creativity, which is characterized by digital technologies and innovations in digital business. Of course, marketing has not been left out and has undergone significant changes in recent times, resulting in the concept of digital marketing. So ehe article establishes that digital marketing is a type of marketing activity that through digital channels by digital methods allows targeted interaction with target market segments in virtual and real environments. The marketing tools of the Internet are studied and the marketing communication strategy in the digital environment is considered as a component of the company's marketing complex, which determines the company's communication influence on market participants through the use of digital influence tools and active process moderation in the communication environment.

Keywords: digital marketing, Internet, communication, promotion, marketing tool, omnichannel marketing.

Беловодская Елена, доктор экономических наук, профессор, Киевский национальный университет имени Тараса Шевченко, кафедра международной экономики и маркетинга,

г. Киев

Головачов Иван, Киевский национальный университет технологий и дизайна, соискатель третьего (образовательно-научного) уровня высшего образования по специальности 075 «Маркетинг», г. Киев

\section{СИСТЕМНОЕ ИССЛЕДОВАНИЕ ИНСТРУМЕНТОВ СТРАТЕГИИ ЦИФРОВОГО МАРКЕТИНГА}

В XXI веке, когда быстро развиваются технологии и есть неограниченный доступ к информации, нельзя отрицать, что мир, в котором мы живем, стремительно меняется. Быстрые темпы развития науки, глобализация, переход к информационному обществу и цифровая экономика способствовали значительной трансформации общества. В настоящее время в мире происходит создание глобального цифрового пространства, поэтому глобализация и диджитализация - основные тренды современности, в большей или меньшей степени охватывают все страны мира. Диджитализация - это общий термин для обозначения цифровой трансформации общества и экономики. Он описывает переход от индустриальной эпохи и аналоговых технологий к эпохе знаний и творчества, которая характеризуется цифровыми технологиями и инновациями в цифровом бизнесе. Конечно, маркетинг не остался в стороне и испытывает значимых изменений в последнее время, в результате чего появилось такое понятие как 
цифровой маркетинг. Поэтому в данной статье установлено, что цифровой маркетинг - это вид маркетинговой деятельности, за цифровыми каналами цифровыми методами позволяет адресно взаимодействовать с целевыми сегментами рынка в виртуальном и реальном средах. Исследованы маркетинговые инструменты в Интернете, рассмотрены стратегии маркетинговой коммуникации в цифровой среде как составляющую маркетингового комплекса компании, которая определяет стратегию коммуникативного воздействия компании на субъектов рынка с помощью использования цифровых инструментов влияния и активной модерации процесса в коммуникационной среде.

Ключевые слова: цифровой маркетинг, Интернет, коммуникация, продвижение, маркетинговый инструмент, многоканальный маркетинг.

Біловодська Олена, доктор економічних наук, професор, Київський національний університет імені Тараса Шевченка, кафедра міжнародної економіки та маркетингу, м. Київ

Головачов Іван, Київський національний університет технологій та дизайну, здобувач третього (освітньо-наукового) рівня вищої освіти зі спеціальності 075 «Маркетинг», м. Київ

\section{СИСТЕМНЕ ДОСЛІДЖЕННЯ ІНСТРУМЕНТІВ СТРАТЕГІЇ ЦИФРОВОГО МАРКЕТИНГУ}

У XXI столітті, коли швидко розвиваються технології і $є$ необмежений доступ до інформації, не можна заперечувати, що світ, в якому ми живемо, стрімко змінюється. Швидкі темпи розвитку науки, глобалізація, перехід до інформаційного суспільства та цифрова економіка сприяли значної трансформації суспільства. В даний час в світі відбувається створення глобального цифрового простору, тому глобалізація та діджиталізація - основні тренди сучасності, які в більшій чи меншій мірі охоплюють всі країни світу. Діджиталізація - це загальний термін для позначення цифрової трансформації суспільства та економіки. Він описує перехід від індустріальної епохи і аналогових технологій до епохи знань і творчості, яка характеризується цифровими технологіями та інноваціями в цифровому бізнесі. Звісно, маркетинг не залишився в стороні та зазнає значущих змін в останній час, внаслідок чого з'явилося таке поняття як цифровий маркетинг. Тож у даній статті встановлено, що цифровий маркетинг - це вид маркетингової діяльності, що за цифровими каналами цифровими методами дає змогу адресно взаємодіяти з цільовими сегментами ринку у віртуальному та реальному середовищах. Досліджено маркетингові інструменти в Інтернеті, розглянуто стратегію маркетингової комунікації в цифровому середовищі як складову маркетингового комплексу компанії, яка визначає стратегію комунікативного впливу компанії на суб'єктів ринку за допомогою використання цифрових інструментів впливу та активної модерації процесу в комунікаційному середовищі.

Ключові слова: цифровий маркетинг, Інтернет, комунікація, просування, маркетинговий інструмент, багатоканальний маркетинг.

Problem statement. In recent years, modern technologies have penetrated into all areas of activity. The Internet has become an effective means of conducting modern business, marketing research. In crisis situations, the role of digital technologies is especially growing, they help companies not only reduce the cost of promotion and sales, but also help entrepreneurs to develop new and expand existing markets for their products, increase the personalization of advertising messages and their effectiveness. Also development of the marketing strategy of the company is a process of creation and practical implementation of the general program of actions of the company. Its goal is the efficient allocation of resources to reach the target market. The subject of marketing strategy is to address the issues of what products (strategic spaces) should be developed by the company and how it can be done.

At the present stage of development there is a significant change in consciousness and lifestyle of people under the influence of informational and socio-cultural factors. The use of marketing 
tools such as regular advertising, sales promotion, etc. is no longer enough to promote a product or brand, because they do not affect the minds of consumers and usually do not bring the maximum effect.

Analysis of recent research and publications. The theoretical basis of the digital transformation of all modern social processes was the concept of the knowledge economy of post-industrial society, which was formed by such prominent scientists as D. Bell [1], J. Galbraith [2], A. Toffler [3] and others. In social production, the digital transformation is a change caused by the influence of interrelated factors: the latest technologies, changes in consumer behavior and new business models.

However, the issue of systematic research of digital marketing strategy tools remains unresolved.

The purpose of the article. The aim of the article is a systematic study of the tools of digital marketing strategy in accordance with the peculiarities of interaction with customers and business partners.

Results. Marketing activities in the modern world are based on the concept of integrated marketing communications. This concept involves the planning of marketing communications, which requires an assessment of the role of each of its elements (advertising, PR, personal sales, sales promotion, exhibitions, packaging, direct marketing, etc.) in the promotion strategy, as well as finding their optimal combination to ensure effective influence of the company's communication programs to promote the brand.

An integral part of the modern set of integrated marketing communications is digital marketing and its tools designed to attract all digital channels to promote the brand. Digital marketing is an influential field today, and at the moment it is digital technology that has the strongest impact on the business world. Digital marketing now accounts for about $25 \%$ of the marketing budgets of leading companies and its share is constantly growing. Businesses that use all available digital channels and communication tools are on average $25 \%$ more profitable than other businesses. Therefore, modern marketers should, above all, have competencies in the field of digital marketing.

Digital marketing is a general term for marketing goods and services that uses digital channels to attract and retain customers. This concept is often identified with Internet marketing. However, digital marketing is not limited to the Internet, but only includes it. In turn, Internet marketing includes SEO promotion of the website, context, webinars, etc., that is, all channels that are available to the user only on the Internet. Digital marketing includes all of the above and advertising and promotion on any digital media offline. That is, it involves digital communication that takes place both online and offline [4].

Digital marketing is a type of marketing activity that allows targeted interaction with target market segments in virtual and real environments through digital channels by using digital methods.

There are a number of tools on the Internet to facilitate the work of the marketer. Among such tools it is advisable to name the following:

1. A company can use the Internet as a way to build and maintain customer relationships. Part of the fundraising transaction can be done online.

2. Potential customers can be generated by registering for a short period of time before registering on a long-term basis.

3. The Internet can be used for advertising, which is the most common type of Internet communication.

4. Finally, the digital environment can be used as a way to collect direct answers, for example as part of a voting system [5].

For example, firstly, when implementing a strategy to promote products on the Internet, companies using digital marketing technology can implement strategies such as: advertising platforms testing strategy; traffic promotion strategy; company image management strategy; proactive promotion strategy; target strategy (sales targeting, pursuit marketing and hunting marketing). Web analytics of the company in the digital marketing system is the most important component, which concentrates the whole set of marketing information obtained from the implementation of the strategy of promoting the company's products on the Internet and the operation of the company's website. This information should be used by the company to make effective management decisions in the production and sale of goods in accordance with the needs and desires of the target market segment in terms of their quality, safety, usefulness, timely organization of the procurement system, etc. 
Secondly, one can consider that the implementation of the advertising platforms testing strategy is the analysis and evaluation of advertising platforms and search queries to assess the volume of demand, determine the cost of achieving marketing goals and the effectiveness of each source of traffic. At the same time, there are different types of advertising. Qualitative results are evaluated as the ratio of the cost of attracting the target audience to the commercial effect (implementation of the marketing objective).

Based on this, employees of the marketing department have the opportunity to obtain information both on the overall demand for each advertising platform (advertising medium) and on the largest source of traffic.

The next step is to consider the marketing communication strategy in the digital environment - a component of the company's marketing complex, which determines the strategy of communicative influence of the company on market participants through the use of digital tools and active moderation in the communication environment. The audience of influence can be both external audiences (consumers, suppliers, competitors, etc.) and internal audiences (employees, partners, etc.). The greatest effectiveness of communication is achieved when using omnichannel marketing [7].

It was analyzed that according to the research of Smart Insights Marketing Intelligence Limited, currently $55 \%$ of companies have a clearly defined digital strategy, but in $38 \%$ of organizations it is integrated into the overall marketing strategy, and in $17 \%$ it is a separate document. Understanding the need to use a digital marketing strategy to grow a business and build a strong brand, many companies face challenges in developing and implementing it.

These include: the lack of clear goals and, accordingly, the digital marketing plan; misunderstanding of the online market due to lack of research on consumer demand and underestimation of customer needs for online services; lack of a strategic approach; lack of a strong online offer; insufficient knowledge of their online customers; lack of integration of digital media with traditional ones; lack of budget allocated for digital marketing; lack or insufficiency of digital skills; duplication of digital marketing functions; lack of flexibility and dynamism in the use of new approaches in business and marketing; lack of reaction to the results of analytics.

The solution of these issues is possible when building a digital marketing strategy. According to the results of the analysis of researches of scientists of the concept of digital marketing in sources, its essential features are revealed (Fig. 1).

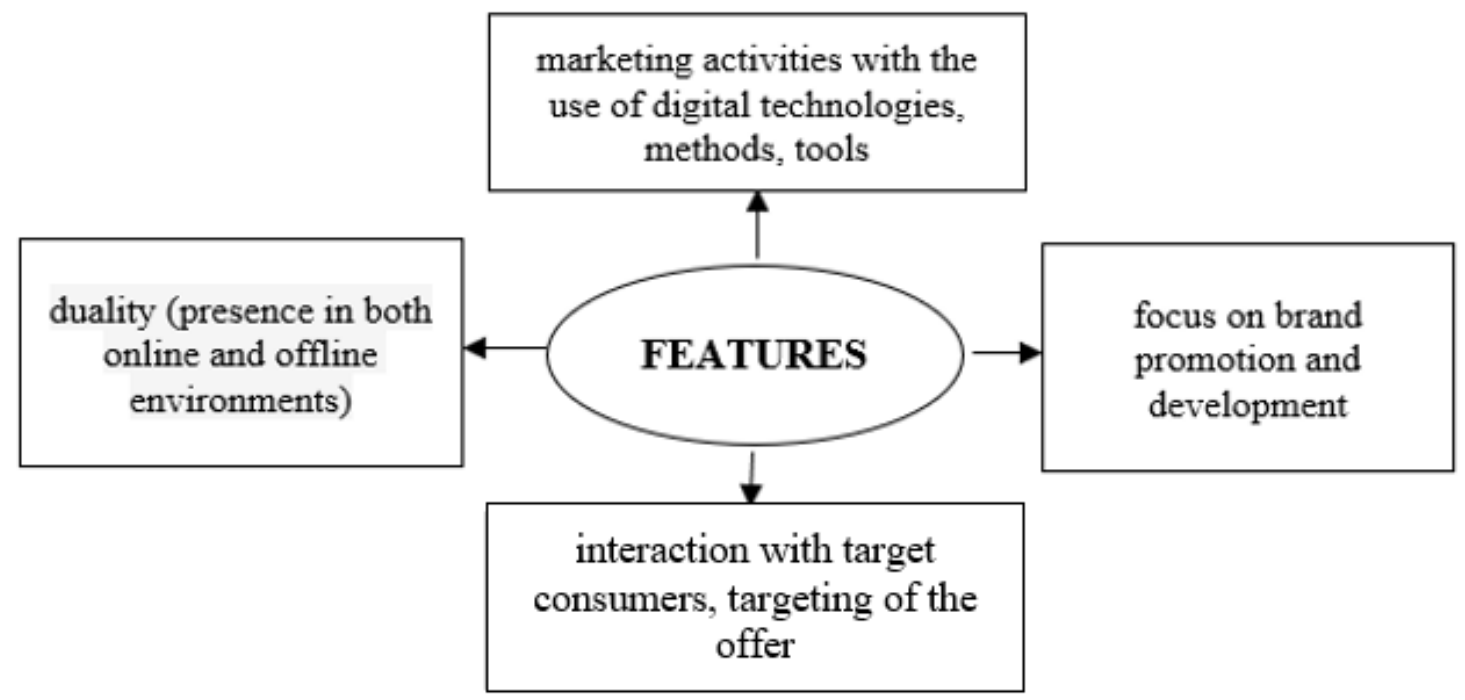

Fig. 1. Essential features of the concept of "digital marketing" [8]

In our opinion, all marketing decisions in modern conditions require the use of innovation and coordination with financial decisions. Because of this, one can use a digital marketing strategy as a plan to achieve marketing objectives based on the principles of digital marketing.

That will include multi-channel integrated marketing communications that take into account the interaction with the client throughout its lifecycle. 
One of the most commonly used online advertising tools is contextual advertising, that is, ads that are displayed according to our search queries. Depending on whether it is a text ad or a media variety of contextual advertising, the basic principle of action is aimed at a specific audience that already needs a specific product or service. The benefit of contextual advertising is also that the payment for it is taken only for the links, while the demonstration is free. SEO or search engine optimization of sites can also be considered a tool of Internet advertising, because it depends on how the promotion was carried out, whether the user will meet your site in the first lines of search results for a particular query. Competent search promotion is always not an individual event, but a set of actions aimed at bringing to the top and maintaining this position, but gives impressive results. Since the popularity of social networks on the Internet is undeniable, we can not ignore the topic of advertising on such resources. This is targeted advertising, which is based on specific data gleaned from profiles, and therefore has a high chance of user feedback. The promotion of goods and services to users of social networks is often successful precisely because of the clear definition of the audience of potential customers, as well as creating an atmosphere of interaction and feedback, for example, through communication in certain groups dedicated to a particular product. Banner advertising can be considered the oldest tool of Internet marketing, but its effectiveness has decreased mainly due to the emergence of a huge number of them. The effectiveness of banner advertising has also been negatively affected by the advent of add-ons to popular browsers that allow you to block the occurrence of advertising banners on websites. For existing customers of the company, you can use such an advertising tool as e-mail distribution, which will acquaint them with the company's news, encourage additional action and increase loyalty. Here it is important to understand the difference between mailing, which the user subscribes to voluntarily, from spam, ie mass mailing to address databases, because few people are happy with spam in the mailbox and therefore companies that use this method of advertising are likely to gain a negative reputation.

Each method of digital marketing has its own tools that are important for success. The leader among digital marketing tools in recent years is content marketing 20\%. In second place, including market and customer understanding and predictive analytics (14\%), in third place - artificial intelligence and machine learning (about 14\%). Also used are social media marketing (10\%), mobile marketing, including mobile advertising, website and application development (9\%), marketing automation, including CRM, behavioral email marketing and web personalization (9\%), conversion rate optimization / improvement of the website (5\%), search engine optimization (4\%). The use of other digital marketing tools in the overall structure ranges from $3 \%$ and below [8].

Summing up, the formation and successful implementation of a digital marketing strategy is ensured by compliance with the principles of digital marketing: person-centeredness, consistency, innovation, mobility and communication, omnichannelity, informativeness, automation and individualization, profitability.

The benefits of digital marketing are as follows:

1. Digital marketing allows to reach both online and offline consumers.

2. Ability to collect clear and detailed data. Almost all user actions in the digital environment are recorded by analytical systems. This allows to make accurate conclusions about the effectiveness of different channels of promotion, as well as to make an accurate portrait of the buyer.

3. Flexible approach. For example, using a QR code on a flyer, it is possible direct a user to a website. And at the same time, it is possible to invite subscribers to a seminar or other offline event thanks to an email list.

Digital marketing is a comprehensive approach to promoting the company and its products in the digital environment.

Thus, digital technologies today are a crucial factor for success and advancement for every area of business, which gives significant competitive advantages.

Conclusion. Digital marketing is marketing that provides interaction with customers and business partners using digital information and communication technologies and electronic devices. In a broader sense, digital marketing means the implementation of marketing activities using digital information and communication technologies. Thus, the use of new information technologies has led to the formation digital marketing, including Internet marketing. Thus Internet marketing differs in high efficiency of communication opportunities to appeal directly to potential consumers at the lowest cost (for traditional instruments). And in order for the company to maintain efficiency 
marketing communications in the digital environment, it needs to use all possible methods and channels of Internet marketing. Prospects for further research in this area should be focused on research the essence of digital environment and its influence on the use of various marketing tools in the different business.

\section{References}

1. Bell D. (1976). The coming of post-industrial society: A venture of social forecasting. N.Y.: Basic Books, 616 p. [in English].

2. Galbraith J. K. (2007). The New Industrial State. Princeton University Press, 576 p. [in English].

3. Toffler A. (n. d.) The Third Wave. Bantam Books, 560 p. http://era.gov.kh/eraasset/uploads/2020/02/Toffler.Alvin_.The_.Third_.Wave_.pdf. Retrieved from 12.07.2021 [in English].

4. Marchuk O. (2018). Tsyfrovyi marketing iak innovatsiinyi instrument upravlinnia [Digital marketing as an innovative management tool]. Economy and society, 17, pp. 296-299. Retrieved from http://economyandsociety.in.ua/journals/17_ukr/43.pdf [in Ukrainian].

5. Hodovaniuk A., Herasymova T. (n. d.) Tsyfrovyi marketynh: trendy ta perevahy [Digital marketing: trends and advantages]. Retrieved from https://conf.ztu.edu.ua/wp-content/uploads/2021/01/323.pdf [in Ukrainian].

6. Romanenko O.O. (2016). Vykorystannia systemy tsyfrovoho marketynhu dlia efektyvnoho vprovadzhennia marketynhovykh stratehii pidpryiemstvamy kharchovoi promyslovosti [The use of digital marketing for the effective implementation of marketing strategies for food enterprises]. Scientific Bulletin of Kherson State University. Series «Economic Sciences», 21 (2), pp. 98-103. Retrieved from http://www.ej.kherson.ua/journal/economic_21/2/26.pdf [in Ukrainian].

7. Saienko D. (2019). Vykorystannia systemy tsyfrovoho marketynhu dlia efektyvnoho vprovadzhennia marketynhovykh stratehii pidpryiemstvamy kharchovoi promyslovosti [Formation of communication strategy of the enterprise in the digital environment]. Retrieved from http://marketing.kpi.ua/files/diplomas/magister/2019/Саєнко.pdf [in Ukrainian].

8. Iankovets T. (2019). Tsyfrovi tekhnolohii pidvyshchennia vartosti brendiv [Digital technologies in increasing brands value]. Herald of Kyiv National University of Trade and Economics, 4, pp. 85-100. Retrieved from http://visnik.knute.edu.ua/files/2019/04/10.pdf [in Ukrainian]. 